\title{
Drivers of Vegetation Development, Biomass Production and the Initiation of Peat Formation in a Newly Constructed Wetland
}

\author{
Ciska C. Overbeek,,${ }^{1,5 *} \odot$ Sarah Faye Harpenslager, ${ }^{2,6}$ Jeroen P. van Zuidam, ${ }^{3,7}$ \\ E. Emielvan Loon, ${ }^{4}$ Leon P. M. Lamers, ${ }^{2}$ Merel B. Soons, ${ }^{3}$ Wim Admiraal,${ }^{1}$ \\ Jos T. A. Verhoeven, ${ }^{3}$ Alfons J. P. Smolders, ${ }^{2}$ Jan G. M. Roelofs, ${ }^{2}$ \\ and Harm G. van der Geest ${ }^{1}$
}

${ }^{1}$ Freshwater and Marine Ecology, Institute for Biodiversity and Ecosystem Dynamics, University of Amsterdam, P.O. Box 94240,1090 GE Amsterdam, The Netherlands; ${ }^{2}$ Department of Aquatic Ecology and Environmental Biology, Institute for Water and Wetland Research, Radboud University Nijmegen, Heyendaalseweg 135, 6525 AJ Nijmegen, The Netherlands; ${ }^{3}$ Ecology and Biodiversity Group, Biology Department, Institute of Environmental Biology, Utrecht University, P.O. Box 800.84, 3508 TB Utrecht, The Netherlands;

${ }^{4}$ Theoretical and Computational Ecology, Institute for Biodiversity and Ecosystem Dynamics, University of Amsterdam,

P.O. Box 94240, 1090 GE Amsterdam, The Netherlands; ${ }^{5}$ Present Address: Water Authority Aa en Maas, Pettelaarpark 70, 5216 PP 's-Hertogenbosch, The Netherlands; ${ }^{6}$ Department of Ecosystem Research, Leibniz-Institute of Freshwater Ecology and Inland Fisheries, Müggelseedamm 301, 12587 Berlin, Germany; ${ }^{7}$ Floron, Radboud University Nijmegen, Toernooiveld 1, 6525 ED Nijmegen, The Netherlands

\begin{abstract}
Newly constructed wetlands are created to provide a range of ecosystem services, including carbon sequestration. Our understanding of the initial factors leading to successful peat formation in such environments is, however, limited. In a new 100ha wetland that was created north of Amsterdam (the Netherlands), we conducted an experiment to determine the best combination of abiotic and biotic starting conditions for initial peat-forming processes. Sediment conditions were the main driver of vegetation development, biomass production and elemental composition during the 3-year study period. Overall, helophytes (Typha spp.) dominated
\end{abstract}

Received 1 June 2019; accepted 7 October 2019; published online 25 October 2019 basins with nutrient-rich conditions, whereas nutrient-poor basins were covered by submerged vegetation, which produced about seven times less aboveground biomass than helophytes. The $\mathrm{C} / \mathrm{N}$ ratios for all plant species and biomass components were generally lower under nutrient-rich conditions and were lower for submerged species than helophytes. Because total basin biomass showed five times higher shoot and ten times higher root and rhizome production for clay and organic than sand sediments, even with some differences in decomposition rates are the conditions in the nutrient-rich basins expected to produce higher levels of initial peat formation. The results suggest that addition of a nutrient-rich sediment layer creates the best conditions for initial peat formation by stimulating rapid development of helophytes. 
Key words: Environmental manipulation; Driving factors; Typha; Submerged vegetation; Aboveground and belowground biomass production; Roots and rhizomes.

\section{HighLights}

- Sediment type drives environmental conditions and vegetation development.

- Nutrient-rich conditions stimulate productive helophyte development.

- Nutrient-rich conditions expected to maximise initial peat formation.

\section{INTRODUCTION}

Wetlands provide important ecosystem services, such as carbon sequestration, flood mitigation, biodiversity facilitation and preservation, nutrient cycling and recreation. In face of global change, the carbon sink function of wetlands, and in particular of peat-forming wetlands on which this study focuses, becomes an essential ecosystem service. Wetlands store approximately a quarter to a third of all soil organic carbon (Maltby and Immirzi 1993; references in Mitra and others 2005; Freeman and others 2012), whereas they only cover approximately four to nine per cent of the global land area (Mitra and others 2005; Zedler and Kercher 2005; Davidson and others 2018). Over the last centuries, a large fraction of global wetlands have been lost, drained or degraded (Zedler and Kercher 2005; Davidson 2014), with local losses as high as $87 \%$ (Davidson 2014). Since restoration and rewetting of degraded wetlands do not always restore former ecosystem services (Cooper and others 2014; Lamers and others 2014; Harpenslager and others 2015), the construction of new wetlands can become an important tool to alleviate loss of wetlands and their ecosystem services.

Most newly constructed wetlands are not primarily designed for their carbon sequestration potential and peat formation, but for other purposes like water purification, biodiversity facilitation and preservation, production of biomass for use as biofuel or construction material or recreation (Hansson and others 2005; Gómez-Baggethun and Barton 2013; Kuhlman and others 2013; Vymazal 2014; Zhao and others 2015; Wichmann 2017). To turn a newly constructed wetland into a net carbon sink, production of biomass has to exceed decomposition, resulting in the gradual build-up of organic material (Trites and Bayley 2009). Both the production and decomposition of biomass depend on the quality of the organic material (that is, the plant species) and environmental conditions. Since constructed wetlands do not automatically turn into peat-forming wetlands (Zedler 2000; Lamers and others 2002), the future function of the wetland has to be considered in the design phase, not only to create optimal starting conditions but also to maintain suitable conditions during later phases (Borkenhagen and Cooper 2015). Three key aspects are hydrology, vegetation composition and productivity. We elaborate on these key aspects in the subsequent paragraphs.

Hydrological conditions strongly influence wetland functioning (Ketcheson and others 2016), for example by affecting oxygen availability and associated decomposition rates and nutrient mobilisation from the sediment (Lamers and others 2012; Harpenslager and others 2015). Water depth influences the ratio between aboveground and belowground biomass production, with increasing shoot length and decreasing belowground biomass production with increasing water depth (Webb and others 2012), and it influences the ability of macrophytes to germinate and establish (van der Valk 1981). Furthermore, nutrient availability in the system, either through inflow or through sediment mobilisation, should be high enough to sustain biomass production of target species (Sarneel and others 2010; Dee and Ahn 2014), but eutrophic conditions should be avoided to prevent the establishment of algal dominance (Smith 2003).

When aiming at peat formation, production is the first important step. To this purpose, it is crucial that plant species are introduced or can effectively colonise the wetland. The type of vegetation that develops in a newly constructed wetland and the rate at which it colonises the entire wetland depends on multiple factors. Seeds or propagules can be present in the sediment which is used for the construction of the wetland (van der Valk and Verhoeven 1988; Hausman and others 2007; Li and others 2008), or they can be passively introduced by wind (Soons 2006), waterfowl (van Leeuwen and others 2012), water flow (Soomers and others 2013) or via recreation in the area (Cutway and Ehrenfeld 2010). Target species can also be actively introduced. This can be a good solution for target species that mainly reproduce clonally, such as Stratiotes aloides (Smolders and others 1995), or plants that do not occur in the immediate vicinity 
of the wetland and do not have a viable seed population or propagule bank in the constructed wetland (Bakker and others 1996; Gurnell and others 2006). Generally, submerged species and other annuals are among the first to colonise a newly constructed wetland (Bornette and Puijalon 2010). Many so-called standing water species can establish themselves in shallow water bodies, while most emergent vegetation can only establish themselves at locations without standing water because their seeds will float (van der Valk 1981; Soons and others 2017).

Once suitable species have established, the target plant species will have to produce more biomass than is lost through decomposition in order to build up an organic layer. Plant species generally produce more biomass at higher nutrient levels (Fennessy and others 2008; Sarneel and others 2010), but also a high plant functional diversity (for example, species with different growth strategies) has been shown to stimulate biomass production and cover (van Zuidam and others 2018). Due to the very few studies in newly constructed wetlands reporting on belowground biomass production and decomposition, little is known about the relative contribution of belowground and aboveground biomass to initial peat formation in new systems. Nutrient-limiting conditions commonly result in higher biomass allocation to belowground organs, but occasionally also in a larger specific root length (Aerts and Chapin 1999) or a change in the quality of the biomass. The allocation of biomass to a specific organ is not only dependent on nutrient availability, but also on water depth, with helophytes showing higher aboveground biomass with increasing water depth (Coops and others 1996; Webb and others 2012) and higher belowground biomass with increasing species richness (Wang and others 2013). Because decomposition rates are hampered under anoxic conditions, generally more intact belowground plant parts are found in fen peat layers than their aboveground counterparts because roots and rhizomes grow into the generally anoxic sediment layers, whereas aboveground litter falls on the commonly oxic sediment surface when it senesces (Moore 1987). However, aboveground biomass may still contribute substantially to initial peat formation when its production rate exceeds that of belowground biomass.

Although numerous studies have reported on the interaction between environmental conditions and vegetation development, biomass production and decomposition, it is still a major challenge to design a constructed wetland that is rapidly colonised by peat-forming species and successfully develops into an ecosystem similar to natural peatlands in its species composition, processes and ecosystem services within a reasonable time frame. A recent large-scale development of new wetland area 'Volgermeerpolder' near Amsterdam, the Netherlands, allowed us to experiment with abiotic and biotic starting conditions and evaluate the early initiation of peat-forming processes through development of a vegetation with high biomass production but at the same time low litter decomposition rates. This wetland is being developed on top of a former waste dump that was created in this area after the original peatlands were destroyed by commercial peat excavation. Twenty-seven experimental wetland basins were constructed with differences in initial sediment type and water regime, which allowed us to study biomass production and decomposition, their drivers and interactions simultaneously under field conditions for a period of three years. Here, we address the following questions: (1) How do initial conditions of sediment type and water regime drive the development of key abiotic factors over time? (2) How do initial conditions of sediment type and water regime determine vegetation composition and density? and (3) How does the combined effect of abiotic factors and vegetation composition determine the production and quality of plant biomass, and its potential for peat formation? By studying the drivers for environmental conditions, vegetation development and aboveground and belowground biomass production simultaneously, we can better understand the optimal conditions for biomass production that is needed for initial peat formation. This information will be very important when developing new constructed wetlands to alleviate the loss of fully developed wetlands and their ecosystem services.

\section{Materials ANd Methods}

\section{Site Description}

The Volgermeerpolder $\left(52^{\circ} 25^{\prime} 17^{\prime \prime} \mathrm{N} ; 4^{\circ} 59^{\prime} 35^{\prime \prime}\right.$ E), a wetland area located $3.5 \mathrm{~km}$ northeast of the city of Amsterdam in the Netherlands, was constructed in 2004-2011 on top of a 100-ha former waste dump. The design for the sanitation of the large dumpsite with hazardous household and industrial waste involved covering the complete site with a layer of sand for stabilisation purposes topped with a 2-mm thick layer of high-density polyethylene (HDPE, Dijcker and others 2011), which was subsequently covered with a layer of clean sand (Buijs and others 2005). Because the 
lifespan of the HDPE is limited to 50-100 years, the aim was to develop a peat-forming wetland on top in this relatively short time frame to provide a sustainable, long-term cap on top of the toxic waste.

The landscape plan with many fold wetland basins (design by Vista Landscape Architecture and Urban Planning, Amsterdam, the Netherlands, development by Advice Combination Volgermeer (ACV), the Netherlands, Egbring 2011) provided a unique opportunity to study initial peat formation under realistic conditions. By placing clay dikes, 27 experimental basins were created in the western part of the wetland which was dedicated to research, with areas ranging from 550 to $1600 \mathrm{~m}^{2}$ (Figure 1; see Electronic Supplementary Material (ESM) A, tab 'area_treatment', for an overview of the treatment and area per basin, with area divided into shore (first $2 \mathrm{~m}$, with gradient) and middle (rest of basin, flat)). The substrate in nine basins was supplemented with $20 \mathrm{~cm}$ of organic sediment (originating from a nearby peatland area, $52^{\circ} 17^{\prime}$ $13^{\prime \prime} \mathrm{N}, 4^{\circ} 46^{\prime} 12^{\prime \prime} \mathrm{E}$ ), while the substrate in nine other basins was supplemented with $20 \mathrm{~cm}$ of clay (originating from a freshwater wetland in the northwest of the Netherlands, $52^{\circ} 40^{\prime} 15^{\prime \prime} \mathrm{N}, 5^{\circ} 7^{\prime}$ $2^{\prime \prime}$ E). The basins with three sediment types ("sand", 'clay' and 'organic') were subjected to one of three water regimes: (1) rainwater, with water level kept at $60 \pm 15 \mathrm{~cm}$ ('rain'), (2) mixture of rain and nutrient-rich surface water from the surrounding agricultural area, with water level in the first 2 years kept at $60 \pm 15 \mathrm{~cm}$ and in the third year at a fluctuating level of 20-75 cm ("mixture") and (3) nutrient-rich surface water from the surrounding agricultural area, with water level kept at $60 \pm 15 \mathrm{~cm}$ ("agriculture"), resulting in nine triplicate treatments (Figure 1). When water levels in the basins dropped below the minimum level during drought or were raised above the maximum, water was supplied or removed using a pump with a fine mesh screen (mesh size $0.3 \mathrm{~mm}$ ) to prevent the translocation of species to the basins. A separate basin with sand sediment, dedicated for the storage of rainwater, was used to supply rainwater to the rain and mixture water treatments in case of water shortages.

\section{Environmental Variables}

Sediment and water samples were taken in all basins as previously described in Harpenslager and others (2018), Overbeek and others (2018b) and Overbeek and others (2018a).

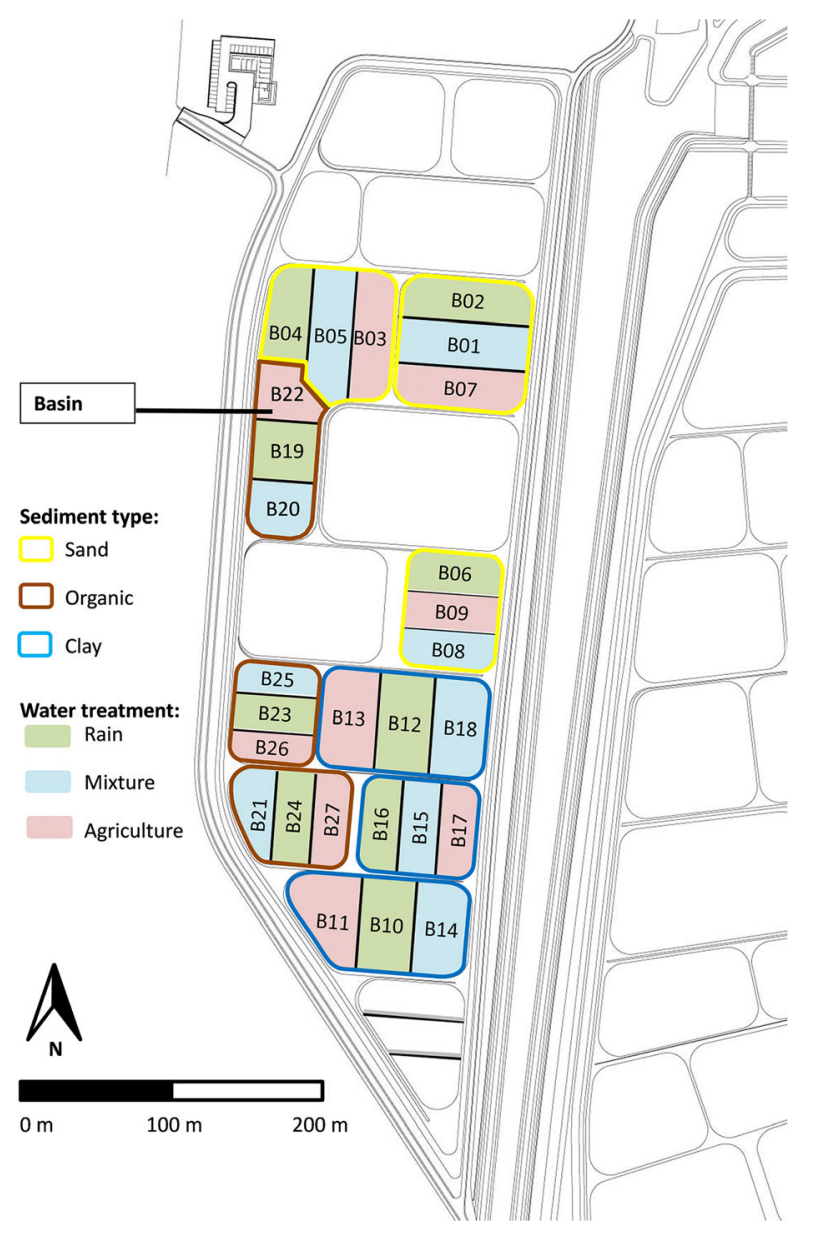

Figure 1. Overview of experimental basins in the Volgermeerpolder, the Netherlands, with three sediment types (sand, clay and organic, further characterised in Table 1) and three water regimes (rain-rainwater with a fixed water level; mixture-a mixture of rain and nutrient-rich surface water from the surrounding agricultural area, with a fixed water level in the first 2 years and a varying water level in the third year; agriculture-nutrient-rich surface water from the surrounding agricultural area with a fixed water level). Basin codes indicate organic matter content in sediment as measured in 2014, with B01 having the lowest content $(0.3 \%)$ and B27 the highest $(27.7 \%)$ (see ESM A, tab 'SED' for organic matter content for all basins). For an impression of the field situation, see the photographs in ESM D.

Sediment (SED) samples were collected in February 2014, by pooling five subsamples of the top $10 \mathrm{~cm}$ per basin with a volume of $50 \mathrm{ml}$ per subsample. After collection, samples were stored in airtight bags at $4{ }^{\circ} \mathrm{C}$ until further analysis. Water content (Moisture) and bulk density (BulkDensity) were determined by weighing and drying samples of known volume for $48 \mathrm{~h}$ at $70{ }^{\circ} \mathrm{C}$. Organic matter (OM) content was determined through loss on 
ignition at $550{ }^{\circ} \mathrm{C}$ for $3 \mathrm{~h}$. Carbon (C) and nitrogen (N) contents of the dried sediment were determined using an elemental analyser (Carlo Erba NA1500, Thermo Fisher Scientific, Waltham, MA, USA).

Surface water (SW) and pore water (PW) samples were taken in March (only SW), July, November and December (only SW) 2011, January (only SW), April, August, October (only SW) and November 2012, April, June (only SW), July and November 2013 and February, May and July 2014. Pore water was collected by attaching vacuum syringes to ceramic soil moisture cups (Eijkelkamp, Giesbeek, the Netherlands), fixed in the sediment at $15 \mathrm{~cm}$ depth. Alkalinity was determined by titration down to $\mathrm{pH} 4.2$ with $0.1 \mathrm{~N} \mathrm{HCl}$ using an auto-burette with accurately determined titer (ABU901, Radiometer, Copenhagen, Denmark). $\mathrm{pH}$ was measured using a standard $\mathrm{Ag} / \mathrm{AgCl}$ electrode (Orion, Thermo Fisher Scientific, Waltham, MA, USA). Total inorganic carbon (TIC) was measured on an infrared gas analyser (IRGA, ABB Analytical, Frankfurt, Germany), after which the concentrations of carbon dioxide $\left(\mathrm{CO}_{2}^{-}\right)$and bicarbonate $\left(\mathrm{HCO}_{3}{ }^{-}\right)$were calculated from TIC concentrations using $\mathrm{pH}$, temperature and carbonic acid equilibrium constants (Stumm and Morgan 2012). Concentrations of nitrate $\left(\mathrm{NO}_{3}{ }^{-}\right)$, ammonium $\left(\mathrm{NH}_{4}{ }^{+}\right)$and soluble reactive phosphorus (SRP, or ortho-phosphate: $\mathrm{o}-\mathrm{PO}_{4}{ }^{3-}$ ) were analysed colourimetrically for $\mathrm{NO}_{3}{ }^{-}, \mathrm{NH}_{4}{ }^{+}$and SRP on an Auto Analyser 3 System (Bran \& Luebbe, Norderstedt, Germany) using salicylate (Kamphake and others 1967), hydrazine sulphate (Grasshoff and Johannsen 1972) and ammonium molybdate (Henriksen 1965), respectively. Concentrations of total phosphorus (total-P), calcium (Ca), magnesium $(\mathrm{Mg})$, iron $(\mathrm{Fe})$ and sulphur $(\mathrm{S})$ were measured by inductively coupled plasma spectrometry (ICP-OES ICAP 6000, Thermo Fisher Scientific, Waltham, MA, USA).

\section{Vegetation Development}

Vegetation in the basins of the Volgermeerpolder was allowed to develop autonomously. A few square meters of reed clippings were added on the shore just above the waterline at the northeast side of each basin in 2011 to promote vegetation development, and 50 plants of Stratiotes aloides per basin were added in enclosures in the northeast corner of each basin in summer 2011 to promote vegetation development and determine the drivers for development of $S$. aloides (Harpenslager and others 2018). No other seeds or plants were added to the basins, except for those already present in the sediment used for construction of the basins. In the period 2011-2014, yearly vegetation relevees were made at the peak of the growing season (July/ August). One relevee was made for the total surface area of each basin, including all helophyte and macrophyte species growing in the water and on the banks within $30 \mathrm{~cm}$ of the waterline. Plants were identified mostly up to species level (see observed species list in ESM A, tab 'vegetation_names'), and plant cover for the full basin was estimated using Tansley cover classes (see ESM A, tab 'Tansley_classes', for an overview of the classes) (Tansley 1946).

\section{Biomass Production}

At the end of August 2014, 3 years after wetland construction, aboveground and belowground biomass of selected dominant species was sampled from all 27 basins and their areal coverage determined. Submerged and floating species (consisting of Chara spp., Potamogeton crispus, P. pectinatus, P. pusillus, Elodea nuttallii, Myriophyllum spicatum and Lemna trisulca) were harvested and pooled to determine total submerged biomass. Target helophyte species of this study (Typha latifolia, $T$. angustifolia, Phragmites australis, Bolboschoenus maritimus, Glyceria maxima, Eleocharis sp. and Alisma plantago-aquatica) were harvested, and belowground biomass was separated into rhizomes and roots, except for $A$. plantago-aquatica which does not produce rhizomes. Because most submerged species contain far more aboveground biomass than belowground biomass (Engelhardt 2006), only aboveground biomass was collected for those species. Cover (\%) of all species was estimated for the shore (first $2 \mathrm{~m}$, with depth gradient) and middle (rest of basin, flat) section of each basin separately.

Biomass was harvested by placing a 30-by $-30 \mathrm{~cm}$ $\left(0.09 \mathrm{~m}^{2}\right)$ bucket with an open bottom over a representative patch of vegetation and pushing it firmly into the sediment, for all selected plant species separately. Using a long, serrated knife, all rhizomes and roots were cut along the edges of the bucket. After loosening the belowground structures by hand, all biomass was pulled from the bucket and placed in a sieve ( $1 \mathrm{~mm}$ mesh size) and gently rinsed to remove attached sediment particles. Only the selected (group of) species was retained and separated into shoots (aboveground vegetation), rhizomes and roots. Sediment from within the bucket was sieved until no belowground vegetation remained. Separate biomass samples for shoots, 
rhizomes and roots were placed in paper bags and dried for approximately three days at $60{ }^{\circ} \mathrm{C}$ before determining dry weight (DW) and $\mathrm{C}$ and $\mathrm{N}$ content (as described in Environmental Variables section).

Because green shoots die off each year, whereas rhizomes and roots survive winter and remain part of the living plant for several years, we divided rhizome and root biomass by 3 to convert them to yearly average biomass production estimates since vegetation had been allowed to develop for 3 years. Yearly produced rhizome and root biomass were combined into total belowground biomass production. Total plant biomass comprised the combined belowground and aboveground (shoot) biomass production. Carbon-to-nitrogen ratios were determined for each compartment (shoot, rhizome, root, belowground, total) separately. To calculate $\mathrm{C}$ and $\mathrm{N}$ contents of belowground as well as total biomass, the dry weights of all separate parts making up the group were used as weighing factors. The ratio of yearly belowground to aboveground biomass production (BG/AG ratio) was determined by dividing yearly belowground biomass production, including rhizome and root biomass, by aboveground biomass production.

\section{Data Analysis}

\section{Environmental Variables}

Linear models (multiple regression, assuming Gaussian errors) were formulated with sediment characteristics (water content, bulk density, organic matter content, C and $\mathrm{N}$ content, see Environmental Variables section) as response variables, to test for the effect of sediment type (sand, clay, organic-'Sediment') and/or water regime (rain, mixture, agriculture-'Water'). For each response variable, a full model with an interaction term for sediment type and water regime was first fitted (Sediment* Water). When the interaction did not have a significant effect on the response variable, both terms were included only as additive terms (Sediment + Water). If both additive terms were not significant, they were used separately (either Sediment, or Water). For 2011, only sediment type was considered as a predictor variable, because water was added just before sediments were characterised. In summary, the following linear models were considered:

$$
\begin{gathered}
\text { Resp } \sim \text { Sediment } * \text { Water } \\
\text { Resp } \sim \text { Sediment }+ \text { Water } \\
\text { Resp } \sim \text { Sediment }
\end{gathered}
$$

$$
\text { Resp } \sim \text { Water }
$$

with Resp indicating the response variable used. To test for differences between groups, a Tukey post hoc test was performed, using a 0.05 significance level. For models with $p$ values between 0.02 and 0.05 , we checked whether the model assumptions of normality, homoscedasticity (homogenous variance) and no bias (no structural deviation in residuals) were met. When at least one assumption was violated, the model was considered inadequate and not significant.

Surface and pore water samples were measured multiple times per year, for 2011-2014. The models with these variables as response (alkalinity, $\mathrm{pH}$, inorganic carbon, several macronutrients and micronutrients, see Environmental Variables section), included linear time since the start of the experiment (January 1st, 2011) to describe any first-order trend over time and mean monthly air temperature to account for seasonal effects. The air temperature data were obtained from the nearest meteorological station at $20 \mathrm{~km}$ from the experimental site (Schiphol, the Netherlands; Royal Netherlands Meteorological Institute KNMI station $240,52^{\circ} 18^{\prime} \mathrm{N}, 4^{\circ} 46^{\prime} \mathrm{E}$ ). To account for repeated measures within the same basin, basin IDs were used as random variables in the linear mixed effect models (lmer). The resulting linear mixed effect models for the surface and pore water variables were:

$$
\begin{aligned}
\text { Resp } \sim & \text { Linear time }+ \text { Temperature }+ \text { Sediment } \\
& * \text { Water }+(1 \mid \text { Basin })
\end{aligned}
$$

$$
\begin{aligned}
\text { Resp } \sim & \text { Linear time }+ \text { Temperature }+ \text { Sediment } \\
& + \text { Water }+(1 \mid \text { Basin })
\end{aligned}
$$

$$
\begin{aligned}
\text { Resp } \sim & \text { Linear time }+ \text { Temperature }+ \text { Sediment } \\
& +(1 \mid \text { Basin })
\end{aligned}
$$

$$
\begin{aligned}
\text { Resp } \sim & \text { Linear time }+ \text { Temperature }+ \text { Water } \\
& +(1 \mid \text { Basin })
\end{aligned}
$$

with Resp indicating the response variable used and (1/Basin) the term to use basin as a random variable. Differences between groups were tested using a Tukey post hoc test for $p$ values between 0.02 and 0.05; model assumptions were tested as explained above. Linear models with a random variable result 
in both a marginal and conditional $R^{2}\left(R_{\mathrm{m}}^{2}\right.$ and $R_{\mathrm{c}}^{2}$, respectively). $R_{\mathrm{m}}^{2}$ assumes the basin is not known, while $R_{\mathrm{c}}^{2}$ assumes the basin is known. Therefore, the closer both $R_{\mathrm{m}}^{2}$ and $R_{\mathrm{c}}^{2}$ are together, the more general the model will be applicable, since this means the basin is not influencing the results.

\section{Vegetation Development}

Surface and pore water variables were used to characterise abiotic conditions relevant for plant growth. Since vegetation relevees were taken on a yearly basis, averages per year were calculated for surface and pore water characteristics and coupled to the vegetation relevees in the corresponding year. Sediment characteristics were only measured in the first and last year and therefore not used to analyse vegetation development data. Some pore water samples contained missing values (only 18 out of 2376 yearly averages were not available, see ESM A, tab 'PW', for a complete overview of all PW samples). Imputation was applied to replace the missing values with the average of the characteristic for the same basin using the other yearly averages as input. Values for the environmental variables were z-transformed $($ mean $=0, S D=1)$ before usage in the analyses.

Relations between vegetation composition and abiotic conditions were analysed using canonical correspondence analysis (CCA) (Oksanen 2007). Measurements from multiple years within the same basin were treated as individual samples. Two missing values (out of 8316 values in total, see ESM A, tab 'relevees') for Tansley cover classes were imputed by taking the mode for the same species over all sampled years. The function envfit from the $\mathrm{R}$ package vegan (Oksanen and others 2018) was used to relate the environmental variables to the CCA ordination.

\section{Biomass Production}

Differences between basins for biomass production per species were analysed only for $T$. latifolia, $T$. angustifolia and submerged species, since the other species were only present in a few basins. Analyses were performed using biomass production density only from vegetated areas, and using a biomass production rate of $0 \mathrm{~kg} \mathrm{DW} \mathrm{m}^{-2}$ year $^{-1}$ for basins where the specific vegetation type was absent. When the cover of a species in a basin was higher than 2 per cent, but biomass production for (part of the components of) that species was unknown (three out of 163 vegetated areas, see ESM A, tab 'biomass_species'), biomass dry weight was imputed for all components of that species by taking the average of the same species and component in all basins with the same sediment type and water regime.

Biomass production per basin was calculated while accounting for vegetated and unvegetated areas of T. latifolia $(N=24)$, T. angustifolia $(N=18)$, submerged vegetation $(N=19), B$. maritimus $(N=1)$, G. maxima $(N=3)$, Eleocharis sp. $(N=1)$ and $P$. australis $(N=3)$ (ESM A, tab 'cover'). To calculate the vegetated area per species, the percentage cover per species for both middle and shore was multiplied by the surface area of the corresponding section and subsequently divided by the total basin area. By combining the biomass production from the vegetated area per basin for all species present within that basin, we determined the total biomass production per basin per year and subsequently transformed this into biomass production per $\mathrm{m}^{2}$ per basin per year to be able to make comparisons between basins of different sizes.

Linear models were used to test whether originally applied sediment type (sand, clay, organic) and/or water regime (rain, mixture, agriculture) influenced dry weight biomass production (shoot, rhizome, root, belowground, total), $\mathrm{C}$ and $\mathrm{N}$ content and $\mathrm{C} / \mathrm{N}$ ratio of biomass, cover per species and $\mathrm{BG} / \mathrm{AG}$ ratio. The resulting linear models were as specified in Eqs. 1-4. A Tukey post hoc test was performed to test for differences between groups, using a 0.05 significance level. When any model assumption of normality, homoscedasticity or no bias was violated for models with $p$ values between 0.02 and 0.05 , these models were considered to be nonsignificant.

\section{Statistical Software}

All analyses were performed in $\mathrm{R}$ ( $\mathrm{R}$ Core Team 2018), using functions from the packages plyr (Wickham 2011), dplyr (Wickham and others 2017), stringr (Wickham 2018), vegan (Oksanen and others 2018), lme4 (Bates and others 2015), lmerTest (Kuznetsova and others 2017), ggplot2 (Wickham 2009), MuMIn (Barton 2018), emmeans (Lenth 2018) and multcompView (Graves and others 2015).

\section{Results}

\section{Environmental Variables}

The sediment types applied in the basins resulted in significantly different physicochemical conditions. Organic matter content and $\mathrm{C}$ and $\mathrm{N}$ content were highest for organic ( $23 \% \mathrm{OM})$, intermediate for 
clay (5\% OM) and lowest for sand ( $1 \% \mathrm{OM})$ sediments (Table 1; OM: $p<0.001, R_{\text {adj }}^{2}=0.959, \mathrm{~N}$ : $p<0.001, \quad R_{\text {adj }}^{2}=0.943, \quad$ C: $p<0.001, \quad R_{\text {adj }}^{2}=$ 0.951 , see ESM B and C for statistics). $\mathrm{C} / \mathrm{N}$ ratios did not differ between treatments. Water content was highest for organic, intermediate for clay and lowest for sand sediments, whereas the opposite was found for bulk density (Table 1; Moisture: $p<0.001, R_{\mathrm{adj}}^{2}=0.969$, BulkDensity: $p<0.001$, $\left.R_{\text {adj }}^{2}=0.867\right)$.

For all three sediment types, the $\mathrm{pH}$ and alkalinity in the pore water were high, and alkalinity continued to increase over time (Table 2; $p=0.018$, ESM B and C). The alkalinity for sediments with an additional layer of clay or organic sludge was even higher than that for sand sediments ( $\sim$ twice as high, $p<0.001, R_{\mathrm{m}}^{2}=0.440$ and $R_{\mathrm{c}}^{2}=0.696$ ) due to elevated levels of $\mathrm{HCO}_{3}{ }^{-}$ (Table 2; $p<0.001, R_{\mathrm{m}}^{2}=0.327$ and $R_{\mathrm{c}}^{2}=0.458$ ). $\mathrm{CO}_{2}$ levels were also twice as high for basins with clay or organic sediments (Table 2; $p<0.001$, $R_{\mathrm{m}}^{2}=0.201$ and $\left.R_{\mathrm{c}}^{2}=0.241\right)$. The water regime did not influence the pore water characteristics (ESM $C)$. Organic and clay sediments showed higher concentrations of Ca $\left(p<0.001, R_{\mathrm{m}}^{2}=0.439\right.$ and $\left.R_{\mathrm{C}}^{2}=0.538\right)$ than sand sediments, whereas concentrations of $\mathrm{Mg}$ were only elevated for organic sediments (Table 2; $p<0.001, R_{\mathrm{m}}^{2}=0.456$ and $\left.R_{\mathrm{C}}^{2}=0.548\right)$. Pore water $\mathrm{Fe}$ and $\mathrm{S}$ did not differ between treatments (ESM C). Concentrations of SRP and total-P in the pore water (Table 2; SRP: $p=0.001, \quad R_{\mathrm{m}}^{2}=0.207$ and $R_{\mathrm{c}}^{2}=0.360$, total-P: $p<0.001, R_{\mathrm{m}}^{2}=0.352$ and $R_{\mathrm{c}}^{2}=0.387$ ) were four times higher for organic sediments, with concentrations of SRP more than ten times lower than total-P. However, concentrations of SRP may be underestimated because of chemical reactions with Fe during the analyses. No differences were found in $\mathrm{NO}_{3}{ }^{-}$and $\mathrm{NH}_{4}{ }^{+}$concentrations in the pore water between treatments (ESM C). Most pore water variables also changed over time or showed seasonal patterns (ESM C).
Surface water variables mostly changed over time and followed seasonal patterns. They were significantly related to either sediment type, water regime or the combination of both (ESM C). $\mathrm{pH}$ and alkalinity in the surface water were high (Table 2), as in the pore water. Alkalinity increased over time $(p<0.001$, ESM B and C) and was highest for clay and organic sediments (Table 2; $p=0.017, R_{\mathrm{m}}^{2}=0.287$ and $\left.R_{\mathrm{c}}^{2}=0.468\right) . \mathrm{HCO}_{3}{ }^{-}$levels were significantly related to sediment type, but when testing for differences between sediment types, the $p$ value increases slightly causing the $p$ value to not be significant anymore at the 0.05 level (Table 2; $p=0.045, R_{\mathrm{m}}^{2}=0.111$ and $R_{\mathrm{c}}^{2}=$ 0.372). $\mathrm{CO}_{2}$ levels did not differ between treatments. Ca concentrations for organic sediments $\left(p=0.002, R_{\mathrm{m}}^{2}=0.205\right.$ and $\left.R_{\mathrm{c}}^{2}=0.305\right)$ and Fe for clay sediments (Table 2; $p=0.004, R_{\mathrm{m}}^{2}=0.042$ and $\left.R_{\mathrm{c}}^{2}=0.053\right)$ were higher than for sand sediments. Concentrations of $\mathrm{Mg}$, however, were not related to sediment type but to water regime $(p<0.001$, $R_{\mathrm{m}}^{2}=0.161$ and $\left.R_{\mathrm{c}}^{2}=0.206\right)$ and were higher for the agriculture water regime. Concentrations of surface water $S$ did not differ between treatments (ESM C). Contrary to our expectations, $\mathrm{NO}_{3}{ }^{-}$, $\mathrm{NH}_{4}{ }^{+}$, SRP and total-P did not differ between water regimes and were low for all basins, with concentrations of SRP mainly below $1.0 \mu \mathrm{mol} \mathrm{l}^{-1}$ (ESM B). However, $\mathrm{NH}_{4}{ }^{+}$and SRP did differ slightly between sediment types (Table $2 ; \mathrm{NH}_{4}^{+}: p=0.010$, $R_{\mathrm{m}}^{2}=0.059$ and $R_{\mathrm{c}}^{2}=0.059$, SRP: $p=0.012, R_{\mathrm{m}}^{2}=$ 0.107 and $R_{\mathrm{C}}^{2}=0.173$ ), with clay sediments showing two times higher $\mathrm{NH}_{4}{ }^{+}$concentrations and organic sediments showing four times higher SRP concentrations then sand sediments. Total-P did not differ between treatments (ESM C).

\section{Vegetation Development}

The vegetation in the basins developed rapidly in the 3 years after construction of the Volgermeerpolder. In basins with sand sediment, the vegeta-

Table 1. Sediment Characteristics as Measured in 2014

\begin{tabular}{llccc}
\hline Variable & Unit & Sand & Clay & Organic \\
\hline Water content & $\%$ & $20.1 \pm 3.3(9)^{\mathrm{a}}$ & $41.0 \pm 4.1(9)^{\mathrm{b}}$ & $65.0 \pm 2.2(9)^{\mathrm{c}}$ \\
Bulk density & $\mathrm{kgFW} / \mathrm{l} \mathrm{F}$ & $1.97 \pm 0.12(9)^{\mathrm{c}}$ & $1.67 \pm 0.10(9)^{\mathrm{b}}$ & $1.35 \pm 0.07(9)^{\mathrm{a}}$ \\
Organic matter & $\%$ & $0.5 \pm 0.2(9)^{\mathrm{a}}$ & $4.7 \pm 1.6(9)^{\mathrm{b}}$ & $22.7 \pm 3.1(9)^{\mathrm{c}}$ \\
Percentage N & $\mathrm{mg} / \mathrm{mg} \mathrm{DW} * 100 \%$ & $0.04 \pm 0.01(9)^{\mathrm{a}}$ & $0.16 \pm 0.03(9)^{\mathrm{b}}$ & $0.49 \pm 0.07(9)^{\mathrm{c}}$ \\
Percentage C & $\mathrm{mg} / \mathrm{mg} \mathrm{DW} * 100 \%$ & $0.80 \pm 0.26(9)^{\mathrm{a}}$ & $2.70 \pm 0.44(9)^{\mathrm{b}}$ & $9.94 \pm 1.49(9)^{\mathrm{c}}$ \\
C/N ratio & - & $18.4 \pm 3.4(9)$ & $17.3 \pm 3.7(9)^{2}$ & $20.2 \pm 0.6(9)$
\end{tabular}

Sediment characteristics (mean $\pm S D(N)$ ) for basins in Volgermeerpolder as measured in 2014. Different superscript letters indicate significant differences between sediment types $(p<0.05)$. When no superscript letters are present, differences are not significant (ESM C for details). 
Table 2. Surface and Pore Water Characteristics as Measured in 2011-2014

\begin{tabular}{|c|c|c|c|c|}
\hline Variable & Unit & Sand & Clay & Organic \\
\hline \multicolumn{5}{|l|}{ Surface water } \\
\hline Alkalinity & meq/l & $2.3 \pm 0.7(143)^{\mathrm{a}}$ & $3.0 \pm 1.3(143)^{\mathrm{b}}$ & $3.0 \pm 0.9(144)^{\mathrm{b}}$ \\
\hline $\mathrm{pH}$ & - & $8.1 \pm 0.5(143)$ & $8.1 \pm 0.6(144)$ & $8.0 \pm 0.6(144)$ \\
\hline $\mathrm{CO}_{2}$ & $\mu \mathrm{mol} / \mathrm{l}$ & $74 \pm 80$ & $161 \pm 215(117)$ & $144 \pm 171(117)$ \\
\hline $\mathrm{HCO}_{3}{ }^{-}$ & $\mu \mathrm{mol} / \mathrm{l}$ & $2047 \pm 898(125)^{a}$ & $2837 \pm 1499(126)^{\mathrm{a}}$ & $2827 \pm 1027(126)^{\mathrm{a}}$ \\
\hline $\mathrm{NO}_{3}{ }^{-}$ & $\mu \mathrm{mol} / \mathrm{l}$ & $2.67 \pm 5.73(144)$ & $2.84 \pm 5.13(143)$ & $2.01 \pm 3.09(144)$ \\
\hline $\mathrm{NH}_{4}^{+}$ & $\mu \mathrm{mol} / \mathrm{l}$ & $2.5 \pm 2.1(144)^{\mathrm{a}}$ & $4.1 \pm 6.0(143)^{b}$ & $2.8 \pm 2.8(144)^{\mathrm{ab}}$ \\
\hline Soluble reactive phosphorus & $\mu \mathrm{mol} / \mathrm{l}$ & $0.3 \pm 0.6(144)^{\mathrm{a}}$ & $0.7 \pm 0.9(143)^{\mathrm{ab}}$ & $1.3 \pm 2.0(144)^{\mathrm{b}}$ \\
\hline Total-P & $\mu \mathrm{mol} / \mathrm{l}$ & $2 \pm 2(144)$ & $5 \pm 9(144)$ & $5 \pm 8(144)$ \\
\hline $\mathrm{Ca}$ & $\mu \mathrm{mol} / \mathrm{l}$ & $2077 \pm 588(144)^{a}$ & $1892 \pm 463(144)^{a}$ & $2517 \pm 888(144)^{\mathrm{b}}$ \\
\hline $\mathrm{Mg}$ & $\mu \mathrm{mol} / \mathrm{l}$ & $687 \pm 258(144)$ & $645 \pm 248(144)$ & $753 \pm 271(144)$ \\
\hline $\mathrm{Fe}$ & $\mu \mathrm{mol} / \mathrm{l}$ & $5 \pm 4(144)^{\mathrm{a}}$ & $11 \pm 21(144)^{b}$ & $3 \pm 3(144)^{a}$ \\
\hline$S$ & $\mu \mathrm{mol} / \mathrm{l}$ & $1778 \pm 694(144)$ & $1151 \pm 679(144)$ & $1892 \pm 1003(144)$ \\
\hline \multicolumn{5}{|l|}{ Pore water } \\
\hline Alkalinity & meq/l & $7.5 \pm 3.3(95)^{\mathrm{a}}$ & $17.9 \pm 6.4(84)^{\mathrm{b}}$ & $19.3 \pm 7.0(95)^{\mathrm{b}}$ \\
\hline $\mathrm{pH}$ & - & $7.0 \pm 0.2(94)$ & $7.0 \pm 0.2(81)$ & $7.1 \pm 0.2(95)$ \\
\hline $\mathrm{CO}_{2}$ & $\mu \mathrm{mol} / \mathrm{l}$ & $1753 \pm 1010(86)^{a}$ & $3419 \pm 1609(73)^{\mathrm{b}}$ & $3368 \pm 1448(88)^{\mathrm{b}}$ \\
\hline $\mathrm{HCO}_{3}{ }^{-}$ & $\mu \mathrm{mol} / \mathrm{l}$ & $7081 \pm 2794(86)^{a}$ & $14,245 \pm 6075(73)^{\mathrm{b}}$ & $15,347 \pm 6111(88)^{\mathrm{b}}$ \\
\hline $\mathrm{NO}_{3}{ }^{-}$ & $\mu \mathrm{mol} / \mathrm{l}$ & $1.87 \pm 1.91(76)$ & $3.20 \pm 3.97(72)$ & $2.54 \pm 3.31(75)$ \\
\hline $\mathrm{NH}_{4}^{+}$ & $\mu \mathrm{mol} / \mathrm{l}$ & $48.4 \pm 50.7(77)$ & $28.8 \pm 29.6(73)$ & $34.0 \pm 50.5(75)$ \\
\hline Soluble reactive phosphorus & $\mu \mathrm{mol} / \mathrm{l}$ & $2.2 \pm 2.4(77)^{\mathrm{a}}$ & $2.4 \pm 3.6(73)^{a}$ & $12.7 \pm 16.4(75)^{\mathrm{b}}$ \\
\hline Total-P & $\mu \mathrm{mol} / \mathrm{l}$ & $36 \pm 48(86)^{a}$ & $65 \pm 55(81)^{a}$ & $167 \pm 123(88)^{b}$ \\
\hline $\mathrm{Ca}$ & $\mu \mathrm{mol} / \mathrm{l}$ & $3970 \pm 1171(86)^{a}$ & $8201 \pm 2827(80)^{\mathrm{b}}$ & $9295 \pm 2863(88)^{\mathrm{b}}$ \\
\hline $\mathrm{Mg}$ & $\mu \mathrm{mol} / \mathrm{l}$ & $1119 \pm 287(95)^{a}$ & $1550 \pm 474(88)^{a}$ & $2345 \pm 768(97)^{b}$ \\
\hline $\mathrm{Fe}$ & $\mu \mathrm{mol} / \mathrm{l}$ & $144 \pm 96(86)$ & $343 \pm 376(80)$ & $191 \pm 129(88)$ \\
\hline S & $\mu \mathrm{mol} / \mathrm{l}$ & $1499 \pm 816(86)$ & $1243 \pm 1629(81)$ & $2208 \pm 2361(88)$ \\
\hline
\end{tabular}

Surface and pore water characteristics (mean $\pm S D(N))$ for basins in Volgermeerpolder as measured in 2011-2014. Different superscript letters indicate significant differences between sediment types $(p<0.05)$. When no superscript letters are present, either water regime is the only important predictor variable (for surface water Mg) or differences are not significant (ESM C for details). See ESM B for characteristics per year, for both sediment type and water regime.

tion mainly consisted of submerged species, whereas some emergent vegetation developed on the shoreline. In basins with an additional layer of clay or organic sediment, emergent vegetation became dominant on both the shore and the deeper central part of the basins.

The canonical correspondence analysis (CCA) of the yearly vegetation relevee data showed a low explained variance of $18.6 \%$ by the first two axes ( 10.0 and $8.6 \%$ by $\mathrm{CAl}$ and $\mathrm{CA} 2$, respectively, ESM C, tab 'MVA'). Although water regime did not influence vegetation composition (Figure 2A), sediment type did, as shown by a clear grouping of sample sites along CA2 (Figure 2B). Orthogonal to the grouping by the applied sediment types is the vegetation development over time along CAl (Figure 2C, number after basin code indicates year of sampling), explaining the largest share of variance in vegetation composition. This marked succession which took place over the 3 years of development diverged from a relatively similar vegetation composition in the various basins in
2011 to a heterogeneous composition in 2014, with mainly aquatic vegetation in sand basins, and helophytes and other vegetation in clay and organic sediments (Figure 2D). Most environmental variables for both surface and pore water increased with CA2 (Figure 2E) and thus with higher organic matter fractions. The ordination axes could explain $31 \%$ of the variation in surface water alkalinity, but especially a considerable amount of variation in pore water variables, like alkalinity, $\mathrm{HCO}_{3}{ }^{-}$, total-P and SRP ( $\mathrm{R}^{2} 32-45 \%$, ESM C, tab 'MVA' for details per environmental variable). Hence, these variables are identified as the variables that are primarily related to vegetation composition.

\section{Biomass Production}

T. latifolia, T. angustifolia and submerged species were dominant species present in most basins three years after wetland construction. In the vegetated areas of the basins, aboveground biomass production of both Typha species was about seven times 

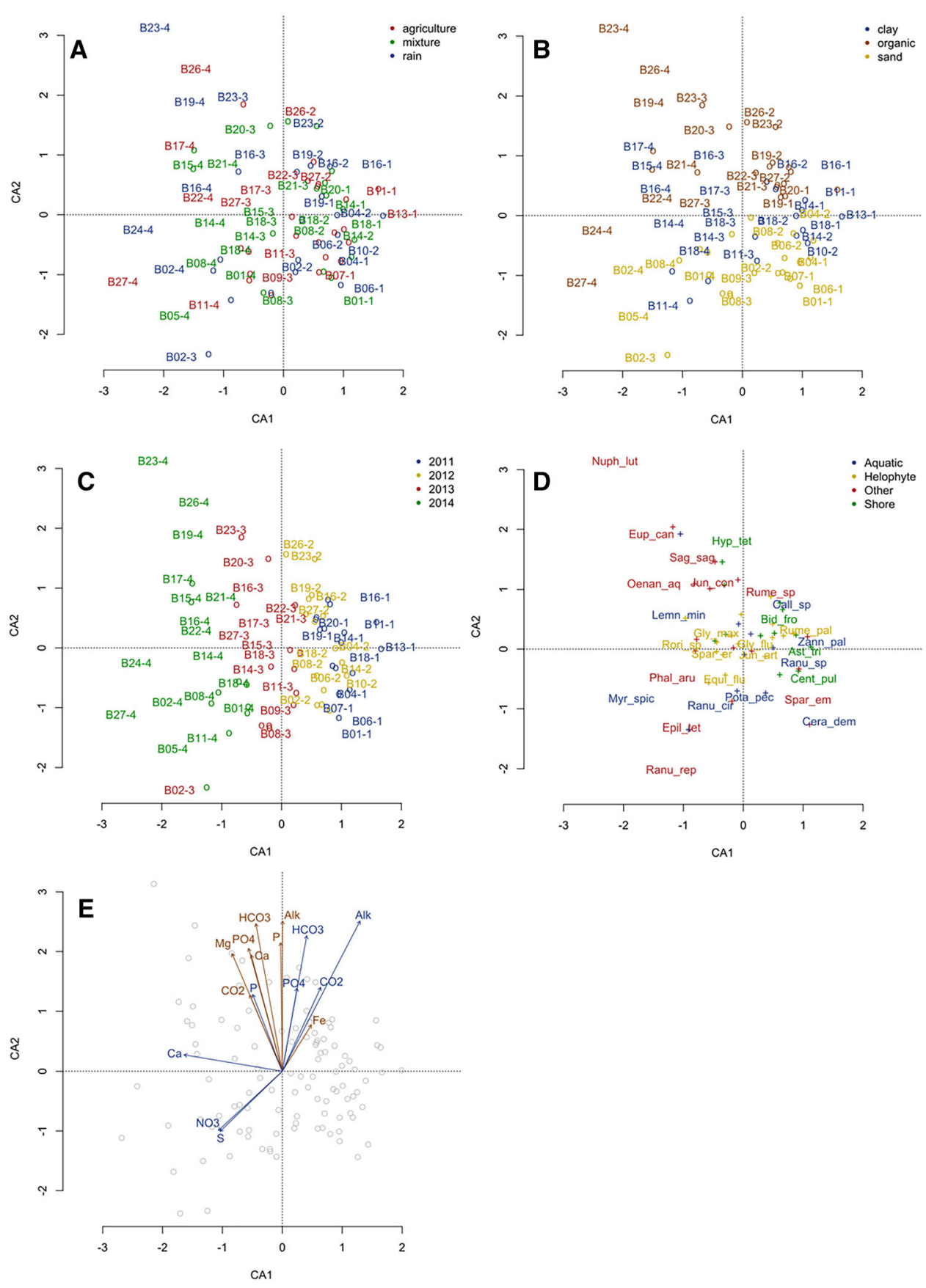

Figure 2. Ordination plots of canonical correspondence analysis (CCA) of vegetation relevees of all 4 years and environmental variables from surface and pore water. The five panels show individual samples (text labels or in case of too much overlap symbols) with colour-coded grouping on $(\mathbf{A})$ water regime, $(\mathbf{B})$ sediment type, $(\mathbf{C})$ year of measurement, (D) vegetation type and (E) environmental variables showing only variables with $p>0.05$ (blue for surface water and red for pore water variables, see ESM A for full names of environmental variables). In panel A-C, samples are shown using the basin code (see Fig. 1 and/or ESM A for corresponding sediment type and water regime) and a number indicating the consecutive years of measurement (for example, B01-1 is basin B01 with sand sediment and mixture water regime, measured in 2011); in panel D abbreviated species names are used (see ESM A for full names).

higher than for submerged species. Both helophyte species produced about five times higher amounts of aboveground than belowground biomass on a yearly basis, taking into account that the belowground biomass was formed in 3 years time. When considering the total basin, including unvegetated 
parts, basins with clay or organic sediment were far more productive than sand basins.

\section{T. latifolia}

After three years, T. latifolia was present in 24 out of 27 basins (ESM A, tab 'cover'), with the highest cover in basins with organic sediment and mixture water regime $(79 \%)$, intermediate cover in basins with organic sediment and rainwater regime $(56 \%)$ and lowest cover in all other basins $(\leq 23 \%$, Table 3; $p_{\text {Sed }}<0.001, p_{\text {Water }}<0.001, p_{\text {interaction }}<$ $0.001, R^{2}=0.814$, ESM B and C). Shoot, rhizome, root, belowground and total biomass productions of $T$. latifolia for vegetated areas, including a biomass production rate of $0 \mathrm{~kg} \mathrm{DW} \mathrm{m}^{-2}$ year $^{-1}$ for basins where it was absent, were all related to sediment type, while root production was also related to water regime. Shoot production was two times higher in clay than in sand sediments $(p=0.048$, $R^{2}=0.072$ ), whereas rhizomes and total belowground biomass were 2.5 times higher in organic than in sand sediments (Figure 3A; DW_rhizome: $p=0.001, \quad R^{2}=0.195, \quad$ DW_belowground: $\quad p=$ $\left.0.001, R^{2}=0.184\right)$. Root production was similar between all treatments, except for a lower production in sand sediment and agriculture water type, and a higher production in organic sediment and rainwater (Figure $3 \mathrm{~A} ; p_{\text {Sed }}=0.038, p_{\text {Water }}=$ $0.046, R^{2}=0.143$ ). Total production was almost two times higher in clay than sand sediments (Figure 3A; $p=0.036, R^{2}=0.082$ ). Belowground/ aboveground production ratios were 1.8 times lower in clay than organic sediment (implying 47.5 times more aboveground than belowground production for organic and clay sediments, respectively, Figure 3A; $p=0.006, R^{2}=0.155$ ).

The $\mathrm{N}$ content was lowest for all belowground vegetation components in sand sediment $\left(p=0.001, R^{2}=0.207\right.$, ESM B and C) and highest in clay sediments for rhizomes $(p=0.001$, $\left.R^{2}=0.218\right)$ and in organic sediments for roots (Table 3; $p<0.001, R^{2}=0.249$ ). The $\mathrm{C} / \mathrm{N}$ ratio of rhizomes steadily increased from clay sediments with agriculture water regimes to sand sediments with mixture water regime (Table 3; 33-110, $\left.p_{\text {Sed }}<0.001, p_{\text {Water }}=0.013, R^{2}=0.407\right)$. Root C/ $\mathrm{N}$ ratio was lower for organic than sand sediments $\left(p=0.013, \quad R^{2}=0.128\right)$, whereas belowground biomass $\mathrm{C} / \mathrm{N}$ ratio increased from clay and organic sediments with agriculture water regime to sand sediments with rain or mixture water regime (Table 3; 35-90, $p_{\text {Sed }}<0.001, \quad p_{\text {Water }}=0.032$,

Table 3. Vegetation Characteristics per Sediment Type and Water Regime

\begin{tabular}{|c|c|c|c|c|c|c|c|c|c|}
\hline & \multicolumn{3}{|l|}{ Sand } & \multicolumn{3}{|l|}{ Clay } & \multicolumn{3}{|c|}{ Organic } \\
\hline & Rain & Mixture & Agriculture & Rain & Mixture & Agriculture & Rain & Mixture & Agriculture \\
\hline \multicolumn{10}{|l|}{ T. latifolia } \\
\hline $\mathrm{BG}: \mathrm{AG}$ & 0.193 & 0.134 & 0.125 & 0.167 & 0.112 & 0.118 & 0.235 & 0.215 & 0.284 \\
\hline Cover & 11 & 6 & 7 & 7 & 17 & 8 & 56 & 79 & 23 \\
\hline $\mathrm{C} / \mathrm{N}$ shoot & 47.2 & 46.4 & 38.0 & 38.7 & 31.3 & 25.4 & 38.7 & 38.9 & 30.7 \\
\hline $\mathrm{C} / \mathrm{N}$ rhizome & 92.2 & 123.8 & 75.2 & 46.7 & 59.7 & 34.2 & 68.4 & 72.5 & 55.6 \\
\hline $\mathrm{C} / \mathrm{N}$ root & 60.2 & 62.5 & 51.8 & 53.2 & 41.4 & 36.4 & 51.7 & 35.9 & 38.8 \\
\hline \multicolumn{10}{|l|}{ T. angustifolia } \\
\hline BG:AG & 0.250 & 0.099 & 0.221 & 0.148 & 0.218 & 0.202 & 0.143 & NA & 0.185 \\
\hline Cover & 1 & 7 & 6 & 25 & 35 & 16 & 8 & 0 & 25 \\
\hline $\mathrm{C} / \mathrm{N}$ shoot & 54.8 & 51.7 & 40.5 & 40.6 & 44.2 & 46.4 & 48.9 & NA & 54.9 \\
\hline $\mathrm{C} / \mathrm{N}$ rhizome & 103.4 & 95.5 & 110.6 & 55.1 & 62.1 & 69.6 & 65.2 & NA & 89.0 \\
\hline $\mathrm{C} / \mathrm{N}$ root & 45.7 & 48.5 & 48.2 & 47.6 & 56.6 & 76.0 & 43.6 & NA & 50.9 \\
\hline \multicolumn{10}{|l|}{ Submerged } \\
\hline BG:AG & NA & NA & NA & NA & NA & NA & NA & NA & NA \\
\hline Cover & 66 & 57 & 44 & 39 & 21 & 49 & 37 & 5 & 32 \\
\hline $\mathrm{C} / \mathrm{N}$ shoot & 21.5 & 22.5 & 17.4 & 17.0 & 16.5 & 18.8 & 21.2 & 22.4 & 18.6 \\
\hline $\mathrm{C} / \mathrm{N}$ rhizome & NA & NA & NA & NA & NA & NA & NA & NA & NA \\
\hline $\mathrm{C} / \mathrm{N}$ root & NA & NA & NA & NA & NA & NA & NA & NA & NA \\
\hline
\end{tabular}

Vegetation characteristics (mean) for T. latifolia, T. angustifolia and submerged species, all per sediment type (sand, clay, organic) and water regime (rain, mixture, agriculture). BG/AG = ratio belowground to aboveground biomass production, cover = percentage species cover, C/N shoot/rhizome/root $=C / N$ ratio for shoot, rhizome and root, see ESM B for mean $\pm S D$ per treatment, sediment type and water regime, and ESM C for differences between groups. Biomass production for the three separate species is presented in Figure $3 A-C$. 


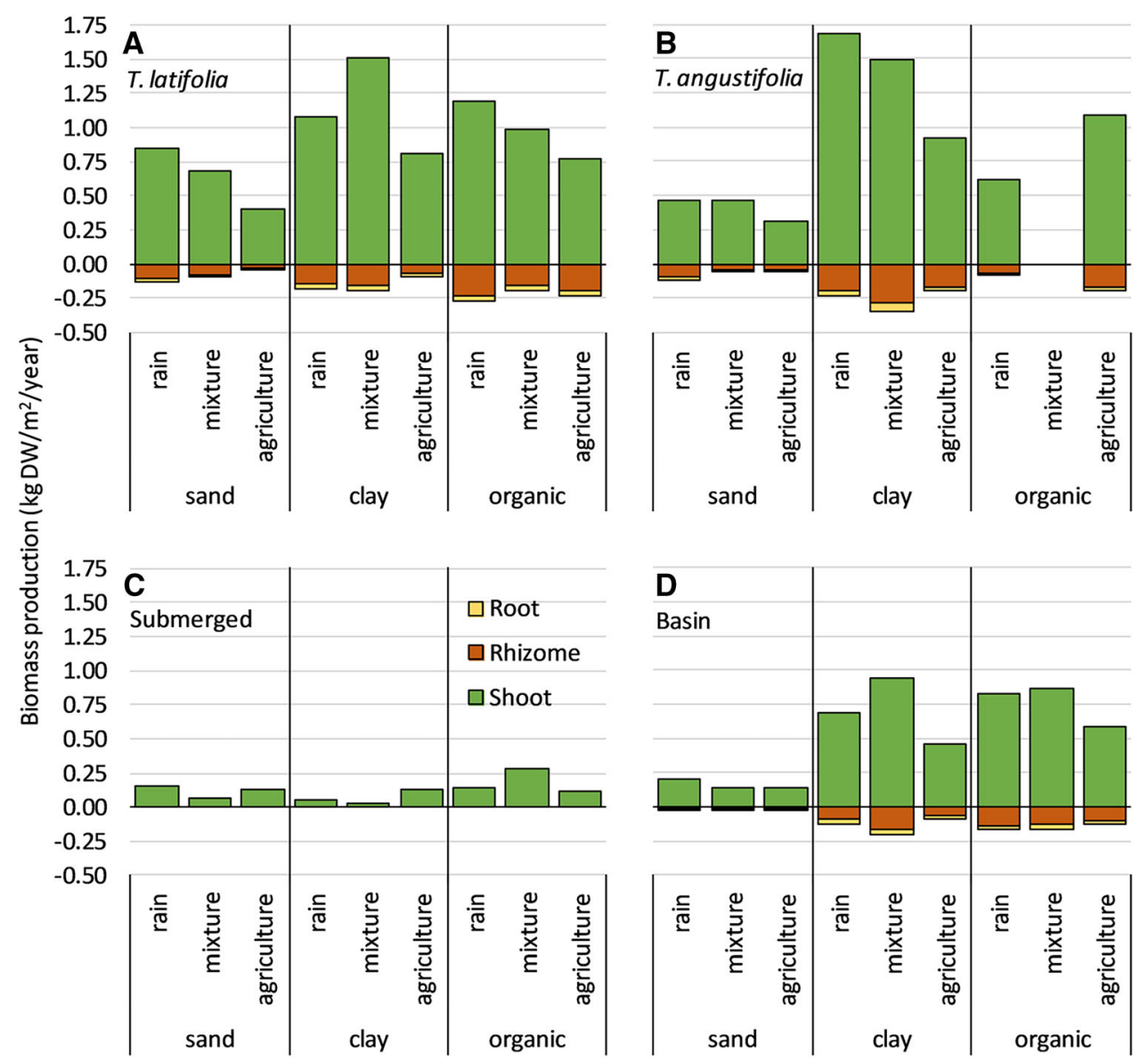

Figure 3. Biomass production (mean, $\mathrm{kg} \mathrm{DW} \mathrm{m}^{-2} \mathrm{year}^{-1}$ ) for vegetated areas for (A) T. latifolia $(N=58),(\mathbf{B}) T$. angustifolia $(N=55),(\mathbf{C})$ submerged species $(N=72)$, and $(\mathbf{D})$ basin averaged production including unvegetated areas $(N=27)$. Values per sediment type (sand, clay, organic) and water regime (rain, mixture, agriculture). Characteristics for the three vegetation types $(\mathbf{A}, \mathbf{B}$ and $\mathbf{C})$ are presented in Table 3.

$\left.R^{2}=0.373\right)$. The N content of shoot and total biomass increased from sand sediments with rain or mixture water regime to clay sediments with agriculture water regime (Table 3; N_shoot: 0.9-1.6, $p_{\text {Sed }}=0.005, p_{\text {Water }}=0.026, R^{2}=0.244, \quad$ N_total: $\left.0.8-1.5, p_{\text {Sed }}=0.002, p_{\text {Water }}=0.013, R^{2}=0.294\right)$. Similar to the shoot and total $\mathrm{N}$ content, the shoot and total $\mathrm{C} / \mathrm{N}$ ratios were related to both sediment type and water regime, showing the opposite trend in range of treatments (Table 3; C/N_shoot: 26-48, $p_{\text {Sed }}=0.011, p_{\text {Water }}=0.036, R^{2}=0.212$, C/N_total: $\left.26-50, p_{\text {Sed }}=0.003, p_{\text {Water }}=0.025, R^{2}=0.257\right)$.

\section{T. angustifolia}

T. angustifolia was present in 18 out of 27 basins. It was completely absent in basins with organic sediment and mixture water regime, and present in all but one basin with clay sediment (ESM A, tab 'cover'). The cover of $T$. angustifolia in sand sediment was generally lowest with values below $8 \%$
(Table 3; $p_{\text {Sed }}<0.001, p_{\text {Water }}=0.501, p_{\text {interaction }}=$ $0.003, R^{2}=0.406$, ESM B and C). Shoot, rhizome, belowground and total biomass productions were related to sediment type in interaction with water regime, with sand sediments generally having the lowest production and clay the highest, with substantial differences between biomass compartments and treatments (Figure 3B; DW_shoot: $p_{\text {Sed }}<$ $0.001, \quad p_{\text {Water }}=0.365, \quad p_{\text {interaction }}=0.008, \quad R^{2}=$ 0.412, DW_rhizome: $p_{\text {Sed }}<0.001, p_{\text {Water }}=0.854$, $p_{\text {interaction }}=0.032, R^{2}=0.301$, DW_belowground: $p_{\text {Sed }}<0.001, \quad p_{\text {Water }}=0.860, \quad p_{\text {interaction }}=0.031$, $R^{2}=0.312, \quad$ DW_total: $p_{\text {Sed }}<0.001, \quad p_{\text {Water }}=$ $\left.0.464, p_{\text {interaction }}=0.010, R^{2}=0.405\right)$. Root production was only significantly related to sediment, with 3-3.5 times higher production for clay sediments (Figure 3B; $p<0.001, R^{2}=0.242$ ). Belowground/aboveground production ratios were significantly related to the interaction between sediment type and water regime (Figure 3B; 
$p_{\text {Sed }}=0.735, \quad p_{\text {Water }}=0.284, \quad p_{\text {interaction }}=0.037$, $R^{2}=0.142$ ); however, treatments did not differ when comparing them separately (ESM C).

Rhizome $\mathrm{N}$ content was higher for clay than sand sediments $\left(p=0.010, \mathrm{R}^{2}=0.215\right.$, ESM B and C), resulting in a lower $\mathrm{C} / \mathrm{N}$ ratio for clay than sand sediments (Table 3; $\left.p<0.001, R^{2}=0.365\right) . \quad \mathrm{N}$ content of root biomass was related to sediment type (Table 3; $p=0.042, R^{2}=0.137$ ), but the treatments were not significantly different from one another when comparing sediment types separately. Root biomass $\mathrm{C} / \mathrm{N}$ ratio did not differ significantly between treatments (ESM C). Belowground biomass $\mathrm{N}$ content did not differ significantly between treatments (ESM C); however, its $\mathrm{C} / \mathrm{N}$ ratio was higher for sand than clay sediment (Table 3; $p=0.046, R^{2}=0.132$ ). Both shoot and total biomass did not show any differences between treatments for both $\mathrm{N}$ content and $\mathrm{C} / \mathrm{N}$ ratio (ESM C).

\section{Submerged Vegetation}

Submerged vegetation was present in 19 out of 27 basins, including all basins with sand sediment (ESM A, tab 'cover'). The species composition of submerged vegetation was more diverse in basins with sand sediment (pers. obs.). Taking absence of submerged vegetation into account as a cover of $0 \%$, cover in sand sediment $(56 \%)$ was higher than in organic sediment $(26 \%$, Table $3 ; \mathrm{p}=0.002$, $\mathrm{R}^{2}=0.136$, ESM B and C), but no differences were found for submerged vegetation biomass production among treatments, with DW for all treatments below $0.18 \mathrm{~kg} \mathrm{DW} \mathrm{m}^{-2}$ year $^{-1}$ (Figure 3C, ESM B and $\mathrm{C}$ ).

Although the $\mathrm{N}$ content was higher for clay than sand sediments (Table 3; $p=0.022, R^{2}=147$ ), the $\mathrm{C} / \mathrm{N}$ ratio did not show any differences between treatments (ESM C).

\section{Whole Basin Biomass}

Biomass production per basin, taking both vegetated and unvegetated areas for all species into account, was generally lower for sand than clay and organic sediments: 4-5 times lower for shoot and total production and 8-12 times lower for rhizome, root and belowground production (Figure 3D; DW_shoot: $\quad p=0.001, \quad R^{2}=0.418$, DW_rhizome: $p=0.001, R^{2}=0.390$, DW_root: $p=0.007, \quad R^{2}=0.287, \quad$ DW_belowground: $p=0.001, \quad R^{2}=0.379, \quad$ DW_total: $\quad p<0.001$, $R^{2}=0.433$, ESM B and C).

It is noteworthy that although some species only occurred in a small number of basins, they made up most of the biomass production within these basins. G. maxima, for example, which covered 37$72 \%$ of the total area in three basins with clay sediment, made up $40-70 \%$ of rhizome and $68-$ $76 \%$ of root production in these basins (ESM B, tab 'basin_species'). P. australis, which covers $7 \%$ of the total area in a basin in which $T$. angustifolia is absent, even makes up $50 \%$ of rhizome and $76 \%$ of root production.

\section{Discussion}

Our experimental field study convincingly shows that biomass production by plant species that might potentially lead to peat formation in newly constructed wetlands is to an important degree determined by nutrient availability in sediment. Water quality, as influenced by different water regimes applied in the basins, was not an important driver of colonisation and biomass production. In treatments with higher nutrient availability, vegetation development quickly resulted in dominance by helophyte species, producing considerable aboveand belowground biomass. In less nutrient-rich environments, basins were dominated by submerged species, producing significantly less biomass and leaving larger parts of the basins unvegetated. Helophytes attained greatest biomass production on organic and clay sediments, while submerged plants attained higher cover on sand sediment and a similar biomass across the three sediment treatments. Effects of different sediment types on Typha spp. growth were previously described by Mollard and others (2013).

Although the fast colonisation of clay and organic basins can to some extent be attributed to the availability of a larger seed bank in the nutrientrich sediments, the majority of the species were present in every experimental basin after the establishment phase so that growth after colonisation is best explained by differences in nutrient availability and sediment characteristics. Initially submerged species that often do not produce roots were present in most basins, but they were outcompeted by rooting clonal dominants like Typha (Reinartz and Warne 1993; Miller and Fujii 2010) in basins with more nutrient-rich sediments. In sand basins, however, submerged species have probably maintained a higher cover because the lower availability of nutrients and higher bulk density prevented the establishment of emergent species (Galatowitsch and van der Valk 1996). Because we observed a marked succession over time, we expect the vegetation communities to further differentiate between sediment types based on the 
environmental conditions present. The management of the water level will most likely be a key factor of further succession since, for example, stable water levels are known to favour the development of Typha spp. (Wilcox 2011). When helophytes are present, they can stimulate further colonisation by creating shallower water depths when their litter accumulates on the sediment (Sarneel and others 2010), thereby providing a positive feedback loop. Furthermore, rhizome growth into open water by emergent species can facilitate entrapment of organic matter in floating mats, thereby creating sites for other species to settle (Homburg 1991). Therefore, although peat formation in sand basins by mainly low-productive submerged species is expected to occur slowly, the dominance of highly productive helophytes in nutrient-rich basins will likely continue to stimulate peat formation.

Values for aboveground biomass production for Typha spp., the most abundant species found in this study, were comparable to values found in the literature (Brinson and others 1981; Fennessy and others 1994; Maddison and others 2009; Vaccaro and others 2009). However, with the prospect of peat formation, it is especially important to focus on the production of roots and rhizomes because those components tend to degrade more slowly and thus potentially contribute more to peat formation per unit biomass produced because they grow and therefore die in mainly anoxic sediments, whereas aboveground litter falls on the commonly oxic sediment surface (Moore 1987; Scheffer and Aerts 2000). Nevertheless, most studies on biomass production in newly constructed wetlands focus on aboveground production, most likely because a lot of those studies focus on wetlands constructed for wastewater treatment (for example, Ennabili and others 1998; Vymazal and Kröpfelová 2005) where aboveground biomass is harvested periodically. In our study, the belowground biomass production by Typha was four to seven times lower than previously reported (Maddison and others 2009). Lenssen and others (1999) showed that less biomass was allocated to roots and rhizomes when nutrient availability was high, but although the organic and clay sediment layers had higher nutrient availability than sand sediment, we either observed no difference or in the case of Typha latifolia even higher relative allocation of biomass to belowground components for nutrient-rich organic sediments. However, in all treatments most biomass was allocated to aboveground biomass, and least to roots. Possibly, the average water depth in our basins was a more important driver than nutrient availability, resulting in this high allocation of biomass to shoots, as previously shown for helophytes by Coops and others (1996). Conversely, the belowground biomass in some basins was almost completely produced by species other than Typha, such as Phragmites australis and Glyceria maxima. Even though their biomass production rates were low compared to the literature (Glyceria maxima: Tanner 1996; Phragmites australis: Kuhlman and others 2013 and references therein), they contributed a high proportion to belowground biomass, up to $72 \%$ in some basins.

Total basin production rates of belowground biomass were about ten times higher under nutrient-rich sediment conditions when compared to sand sediments, and of aboveground biomass about five times higher. These observations illustrate that the ratio between above- and belowground biomass production is not only species dependent, but also influenced by the design of the newly constructed wetland in terms of water levels and sediment composition. Because decomposition rates commonly decrease under anaerobic conditions and in the presence of phenolic compounds (Freeman and others 2001) and are therefore generally lower for rhizomes and roots than for aboveground biomass (Buth 1987; Scheffer and Aerts 2000), these design features ultimately affect organic matter accumulation in these wetlands. Nutrient availability, both directly but also through its effect on litter quality, also influences decomposition rates, with generally higher rates under nutrient-rich conditions or low litter $\mathrm{C} / \mathrm{N}$ ratios (Fennessy and others 2008; Emsens and others 2016). Because species-specific measured $\mathrm{C} / \mathrm{N}$ ratios in this study were generally equal or lower for biomass grown on nutrient-rich sediment types as compared to those grown on sand sediment, slightly higher decomposition rates are expected under nutrient-rich conditions. However, submerged species which were dominant in sand basins generally have lower $\mathrm{C} / \mathrm{N}$ ratios than emergent vegetation ( $\mathrm{Li}$ and others 2013), therefore increasing potential decomposition rates in those basins. The large differences in biomass production rates found in this study, as opposed to the expected relatively small differences in decomposition rates (Overbeek and others 2018b), suggest that especially realisation of sufficiently high biomass production is important for initial peat formation in this wetland. It should, however, be borne in mind that striking the right balance with nutrient supply is crucial: apart from stimulating initial biomass productivity, nutrient-rich sediments do pose a eutrophication risk which may on the long term 
negatively impact the development of suitable vegetation. High levels of alkalinity in surface and pore water in nutrient-rich sediments, which can be further increased by the breakdown of organic matter, can together with $\mathrm{pH}$ influence vegetation community composition by altering microbial processes in the sediment, which can lead to phytotoxicity by resulting in reduced forms of $\mathrm{N}, \mathrm{S}$ and $\mathrm{Fe}$ (Lamers and others 2012). Increased oxygen depletion at the sediment surface can also result in $\mathrm{P}$ mobilisation, thereby potentially causing eutrophication (Roelofs 1991). In our experiment, there were no indications for these negative impacts. Although pore water concentrations of total$\mathrm{P}$ were strongly related to sediment type and explained a high proportion of variation in vegetation composition and abundance, $\mathrm{Fe}: \mathrm{PO}_{4}{ }^{3-}$ ratios were higher than the $1 \mathrm{~mol} \mathrm{~mol}^{-1}$ threshold in all basins, and SRP levels in the surface water mainly remained below $3 \mathrm{~mol} \mathrm{l}^{-1}$. So potential P mobilisation to the water layer and consequent eutrophication are not expected to occur as long as the surface water remains oxic (Geurts and others 2010). The absence of algal blooms during the experimental period supports this expectation. The high availability of $S$ in pore water in all treatments (possibly dominated by sulphate ions) is of some concern in relation to future vegetation development. It may potentially suppress Fe as the most important electron acceptor, thereby resulting in precipitation of FeS and thus subsequent release of $\mathrm{P}$ from the sediment to the water layer and potentially sulphide toxicity (Smolders and Roelofs 1993).

\section{Management Recommendations}

To initiate peat formation on mineral substrate, it is important to stimulate fast colonisation of the wetland by helophytes with high biomass production rates. A water depth of around $60 \mathrm{~cm}$ proved to facilitate also submerged vegetation and colonisation from the banks, whereas preventing noxious algal blooms stimulated by high nutrients. As shown in this study, sediment type is more important than water type in selection of material used for construction of the wetland, because the former has a far greater influence on the development of environmental variables over time, and consequently on the composition and productivity of the vegetation. By applying sediments with a large seed bank of helophyte species, the vegetation development and biomass production can be kickstarted. Helophytes produce a lot of slowly decomposing belowground biomass, which can stimulate initial peat formation. Based on the much higher helophyte cover after addition of clay or organic sediments in our study, we recommend applying such source material.

Because the balance between production and decomposition rates ultimately determines how much biomass is available for peat formation, both processes need to be considered to be able to determine the optimal conditions for stimulation of the initiation of peat formation. Decomposition rates commonly decrease under anaerobic conditions and are therefore generally lower for rhizomes and roots than for aboveground biomass, increasing the importance of the production of belowground biomass for peat formation. Furthermore, biomass with higher nutrient availability, like submerged macrophytes or biomass grown under nutrient-rich conditions, generally has a higher decomposition rate. However, the strong stimulation of both belowground and aboveground biomass production under nutrient-rich conditions by far compensates for the slight increase in decomposition rates. Therefore, we conclude that the addition of nutrient-rich sediments with a large seed bank of helophyte species is an important management tool to stimulate the initiation of peat formation in newly constructed wetlands. To sustain this productivity, caution must be taken to prevent eutrophication.

However, this study also shows that creating peat-forming wetlands is challenging. Biomass production and peat accumulation are complex processes that may be difficult to predict on the long term (see also, for example, Foote 2012). Lost peatlands cannot easily be replaced because of time requirements for peat development and the complexity of reclaiming carbon flows and food web structure (see also, for example, Kovalenko and others 2013). Preserving existing peatlands remains therefore of critical importance.

\section{ACKNOWLEDGEMENTS}

We thank Tamara van Bergen, Peter Cruijssen, Eva van den Elzen, Natan Hoefnagel, Daan Kinsbergen, Anne Kwak, Ernandes Oliviera, Bryndan van Pinksteren, Valerie Reijers, Ariane Scholman, Yingying Tang, Arie Vonk and Kristel van Zuijlen for their help with harvesting biomass, and Jelle Eygensteyn, Sebastian Krosse, Roy Peters, Paul van de Ven and Germa Verheggen for their help with chemical analyses. This research was funded by the Dutch Technology Foundation STW (PeatCap, Project Number 11264) and the municipality of Amsterdam. 


\section{OPEN ACCESS}

This article is distributed under the terms of the Creative Commons Attribution 4.0 International License (http://creativecommons.org/licenses/by/4 $.0 /$ ), which permits unrestricted use, distribution, and reproduction in any medium, provided you give appropriate credit to the original author(s) and the source, provide a link to the Creative Commons license, and indicate if changes were made.

\section{REFERENCES}

Aerts R, Chapin FS. 1999. The mineral nutrition of wild plants revisited: a re-evaluation of processes and patterns. In: Fitter AH, Raffaelli DG, Eds. Advances in Ecological Research, Vol. 30. Cambridge: Academic Press. p 1-67.

Bakker JP, Poschlod P, Strykstra RJ, Bekker RM, Thompson K. 1996. Seed banks and seed dispersal: important topics in restoration ecology. Acta Botanica Neerlandica 45:461-90.

Barton K. 2018. MuMIn: multi-model inference. https://CRAN. R-project.org $/$ package $=$ MuMIn .

Bates D, Maechler M, Bolker B, Walker S. 2015. Fitting linear mixed-effects models using lme4. Journal of Statistical Software 67:1-48.

Borkenhagen A, Cooper JD. 2016. Creating fen initiation conditions: a new approach for peatland reclamation in the oil sands region of Alberta. Journal of Applied Ecology 53:550-8.

Bornette G, Puijalon S. 2010. Response of aquatic plants to abiotic factors: a review. Aquatic Sciences 73:1-14.

Brinson MM, Lugo AE, Brown S. 1981. Primary productivity, decomposition and consumer activity in freshwater wetlands. Annual Review of Ecology and Systematics 12:123-61.

Buijs G, Kaars S, Trommelen J. 2005. Gifpolder Volgermeer, van veen tot veen. Broek in Waterland: Stichting Volgermeerpolder Publicaties

Buth GJC. 1987. Decomposition of roots of three plant communities in a Dutch salt marsh. Aquatic Botany 29:123-38.

Cooper MDA, Evans CD, Zielinski P, Levy PE, Gray A, Peacock M, Norris D, Fenner N, Freeman C. 2014. Infilled ditches are hotspots of landscape methane flux following peatland rewetting. Ecosystems 17:1227-41.

Coops H, van den Brink FWB, van der Velde G. 1996. Growth and morphological responses of four helophyte species in an experimental water-depth gradient. Aquatic Botany 54:1 1-24.

Cutway HB, Ehrenfeld JG. 2010. The influence of urban land use on seed dispersal and wetland invasibility. Plant Ecology 210:153-67.

Davidson NC. 2014. How much wetland has the world lost? Long-term and recent trends in global wetland area. Marine and Freshwater Research 65:934-41.

Davidson NC, Fluet-Chouinard E, Finlayson CM. 2018. Global extent and distribution of wetlands: trends and issues. Marine and Freshwater Research 69:620-7.

Dee SM, Ahn C. 2014. Plant tissue nutrients as a descriptor of plant productivity of created mitigation wetlands. Ecological Indicators 45:68-74.

Dijcker R, van der Wijk M, Artières $O$, Dortland G, Lostumbo J. 2011. Geotextile enabled smart monitoring solutions for safe and effective management of tailings and waste sites. Two case studies: Volgermeerpolder (the Netherlands) and Suncor
(Canada). In: Proceedings Tailings and Mine Waste. Vancouver, $\mathrm{BC}$

Egbring G. 2011. Evaluatierapport Sanering Volgermeerpolder en Randgebieden te Amsterdam 2005-2010. Deventer: Adviescombinatie Volgermeer.

Emsens W-J, Aggenbach CJS, Grootjans AP, Nfor EE, Schoelynck J, Struyf E, Diggelen R. 2016. Eutrophication triggers contrasting multilevel feedbacks on litter accumulation and decomposition in fens. Ecology 97:2680-90.

Engelhardt KAM. 2006. Relating effect and response traits in submersed aquatic macrophytes. Ecological Applications 16:1808-20.

Ennabili A, Ater M, Radoux M. 1998. Biomass production and NPK retention in macrophytes from wetlands of the Tingitan Peninsula. Aquatic Botany 62:45-56.

Fennessy MS, Cronk JK, Mitsch WJ. 1994. Macrophyte productivity and community development in created freshwater wetlands under experimental hydrological conditions. Ecological Engineering 3:469-84.

Fennessy MS, Rokosch A, Mack JJ. 2008. Patterns of plant decomposition and nutrient cycling in natural and created wetlands. Wetlands 28:300-10.

Foote L. 2012. Threshold considerations and wetland reclamation in Alberta's mineable oil sands. Ecology and Society 17(1):35-45.

Freeman C, Ostle N, Kang H. 2001. An enzymic 'latch' on a global carbon store. Nature 409:149.

Freeman C, Fenner N, Shirsat AH. 2012. Peatland geoengineering: an alternative approach to terrestrial carbon sequestration. Philosophical Transactions of the Royal Society of London A: Mathematical, Physical and Engineering Sciences 370:4404-21.

Galatowitsch SM, van der Valk AG. 1996. Vegetation and environmental conditions in recently restored wetlands in the prairie pothole region of the USA. Vegetatio 126:89-99.

Geurts JJM, Smolders AJP, Banach AM, van de Graaf JPM, Roelofs JGM, Lamers LPM. 2010. The interaction between decomposition, net $\mathrm{N}$ and $\mathrm{P}$ mineralization and their mobilization to the surface water in fens. Water Research 44:348795.

Gómez-Baggethun E, Barton DN. 2013. Classifying and valuing ecosystem services for urban planning. Ecological Economics $86: 235-45$.

Grasshoff K, Johannsen H. 1972. A new sensitive and direct method for the automatic determination of ammonia in sea water. ICES Journal of Marine Science 34:516-21.

Graves S, Piepho H-P, Selzer L, Dorai-Raj S. 2015. multcompView: visualizations of paired comparisons. https://CRA N.R-project.org $/$ package $=$ multcompView.

Gurnell AM, Boitsidis AJ, Thompson K, Clifford NJ. 2006. Seed bank, seed dispersal and vegetation cover: colonization along a newly-created river channel. Journal of Vegetation Science 17:665-74.

Hansson L-A, Brönmark C, Nilsson PA, Åbjörnsson K. 2005. Conflicting demands on wetland ecosystem services: nutrient retention, biodiversity or both? Freshwater Biology 50:70514.

Harpenslager SF, van den Elzen E, Kox MAR, Smolders AJP, Ettwig KF, Lamers LPM. 2015. Rewetting former agricultural peatlands: topsoil removal as a prerequisite to avoid strong nutrient and greenhouse gas emissions. Ecological Engineering 84:159-68. 
Harpenslager SF, Overbeek CC, van Zuidam JP, Roelofs JGM, Kosten S, Lamers LPM. 2018. Peat capping: natural capping of wet landfills by peat formation. Ecological Engineering 114:146-53.

Hausman CE, Fraser LH, Kershner MW, de Szalay FA. 2007. Plant community establishment in a restored wetland: effects of soil removal. Applied Vegetation Science 10:383-90.

Henriksen A. 1965. An automatic method for determining lowlevel concentrations of phosphates in fresh and saline waters. Analyst 90:29-34.

Homburg CJ. 1991. Over de vorming van veen, het winnen van turf en de gevolgen voor ons land. Grondboor \& Hamer 45:154-61.

Kamphake LJ, Hannah SA, Cohen JM. 1967. Automated analysis for nitrate by hydrazine reduction. Water Research 1:20516.

Ketcheson SJ, Price JS, Carey SK, Petrone RM, Mendoza CA, Devito KJ. 2016. Constructing fen peatlands in post-mining oil sands landscapes: challenges and opportunities from a hydrological perspective. Earth-Science Reviews 161:130-9.

Kovalenko KE, Ciborowski JJH, Daly C, Dixon DG, Farwell AJ, Foote AL, Frederick KR, Gardner Costa JM, Kennedy K, Liber K, Roy MC, Slama CA, Smits JEG. 2013. Food web structure in oil sands reclaimed wetlands. Ecological Applications 23(5):1048-60.

Kuhlman T, Diogo V, Koomen E. 2013. Exploring the potential of reed as a bioenergy crop in the Netherlands. Biomass and Bioenergy 55:41-52.

Kuznetsova A, Brockhoff PB, Christensen RHB. 2017. lmerTest package: tests in linear mixed effects models. Journal of Statistical Software 82:1-26.

Lamers LPM, Smolders AJP, Roelofs JGM. 2002. The restoration of fens in the Netherlands. Hydrobiologia 478:107-30.

Lamers LPM, van Diggelen JMH, Op den Camp HJM, Visser EJW, Lucassen ECHET, Vile MA, Jetten MSM, Smolders AJP, Roelofs JGM. 2012. Microbial transformations of nitrogen, sulfur, and iron dictate vegetation composition in wetlands: a review. Frontiers in Microbiology: Terrestrial Microbiology 3:156.

Lamers LPM, Vile MA, Grootjans AP, Acreman MC, van Diggelen R, Evans MG, Richardson CJ, Rochefort L, Kooijman AM, Roelofs JGM, Smolders AJP. 2014. Ecological restoration of rich fens in Europe and North America: from trial and error to an evidence-based approach. Biological Reviews 90:182203.

Lenssen JPM, Menting FBJ, van der Putten WH, Blom CWPM. 1999. Effects of sediment type and water level on biomass production of wetland plant species. Aquatic Botany 64:15165.

Lenth R. 2018. emmeans: estimated marginal means, aka leastsquares means. https://CRAN.R-project.org/package=emmea ns.

Li E-H, Liu G-H, Li W, Yuan L-Y, Li S-C. 2008. The seed-bank of a lakeshore wetland in lake Honghu: implications for restoration. Plant Ecology 195:69-76.

Li X, Cui B, Yang Q, Lan Y, Wang T, Han Z. 2013. Effects of plant species on macrophyte decomposition under three nutrient conditions in a eutrophic shallow lake, North China. Ecological Modelling 252:121-8.

Maddison M, Soosaar K, Mauring T, Mander Ü. 2009. The biomass and nutrient and heavy metal content of cattails and reeds in wastewater treatment wetlands for the production of construction material in Estonia. Desalination 246:120-8.

Maltby E, Immirzi P. 1993. Carbon dynamics in peatlands and other wetland soils regional and global perspectives. Chemosphere 27:999-1023.

Miller RL, Fujii R. 2010. Plant community, primary productivity, and environmental conditions following wetland re-establishment in the Sacramento-San Joaquin Delta, California. Wetlands Ecology and Management 18:1-16.

Mitra S, Wassmann R, Vlek PLG. 2005. An appraisal of global wetland area and its organic carbon stock. Current Science 88:25-35.

Mollard F, Roy MC, Foote L. 2013. Typha latifolia plant performance and stand biomass in wetlands affected by surface oil sands mining. Ecological Engineering 38(1):11-19.

Moore PD. 1987. Ecological and hydrological aspects of peat formation. Geological Society, London, Special Publications 32:7-15.

Oksanen J. 2007. Multivariate analysis of ecological communities in R: vegan tutorial. Oulu: University of Oulu.

Oksanen J, Blanchet FG, Friendly M, Kindt R, Legendre $P$, McGlinn D, Minchin PR, O'Hara RB, Simpson GL, Solymos P, Stevens MHH, Szoecs E, Wagner H. 2018. Vegan: community ecology package. https://CRAN.R-project.org/package=vegan.

Overbeek CC, van der Geest HG, van Loon EE, Admiraal W. 2018a. Decomposition of standing litter biomass in newly constructed wetlands associated with direct effects of sediment and water characteristics and the composition and activity of the decomposer community using Phragmites australis as a single standard substrate. Wetlands 39:113-25.

Overbeek CC, van der Geest HG, van Loon EE, Klink AD, van Heeringen S, Harpenslager SF, Admiraal W. 2018b. Decomposition of aquatic pioneer vegetation in newly constructed wetlands. Ecological Engineering 114:154-61.

R Core Team. 2018. R: a language and environment for statistical computing. Vienna, Austria: R Foundation for Statistical Computing http://www.R-project.org/.

Reinartz JA, Warne EL. 1993. Development of vegetation in small created wetlands in southeastern Wisconsin. Wetlands 13:153-64.

Roelofs JGM. 1991. Inlet of alkaline river water into peaty lowlands: effects on water quality and Stratiotes aloides L. stands. Aquatic Botany 39:267-93.

Sarneel JM, Geurts JJM, Beltman B, Lamers LPM, Nijzink MM, Soons MB, Verhoeven JTA. 2010. The effect of nutrient enrichment of either the bank or the surface water on shoreline vegetation and decomposition. Ecosystems 13:127586.

Scheffer RA, Aerts R. 2000. Root decomposition and soil nutrient and carbon cycling in two temperate fen ecosystems. Oikos 91:541-9.

Smith VH. 2003. Eutrophication of freshwater and coastal marine ecosystems a global problem. Environmental Science and Pollution Research 10:126-39.

Smolders A, Roelofs JGM. 1993. Sulphate-mediated iron limitation and eutrophication in aquatic ecosystems. Aquatic Botany 46:247-53.

Smolders AJP, den Hartog C, Roelofs JGM. 1995. Germination and seedling development in Stratiotes aloides L. Aquatic Botany 51:269-79. 
Soomers H, Karssenberg D, Soons MB, Verweij PA, Verhoeven JTA, Wassen MJ. 2013. Wind and water dispersal of wetland plants across fragmented landscapes. Ecosystems 16:434-51.

Soons MB. 2006. Wind dispersal in freshwater wetlands: knowledge for conservation and restoration. Applied Vegetation Science 9:271-8.

Soons MB, de Groot GA, Ramirez MTC, Fraaije RGA, Verhoeven JTA, de Jager M. 2017. Directed dispersal by an abiotic vector: wetland plants disperse their seeds selectively to suitable sites along the hydrological gradient via water. Functional Ecology 31:499-508.

Stumm W, Morgan JJ. 2012. Aquatic Chemistry: Chemical Equilibria and Rates in Natural Waters. New York: Wiley.

Tanner CC. 1996. Plants for constructed wetland treatment systems: a comparison of the growth and nutrient uptake of eight emergent species. Ecological Engineering 7:59-83.

Tansley AG. 1946. Introduction to Plant Ecology: A Guide for Beginners in the Study of Plant Communities. London: George Allen and Unwin Ltd.

Trites M, Bayley SE. 2009. Organic matter accumulation in western boreal saline wetlands: a comparison of undisturbed and oil sands wetlands. Ecological Engineering 25(12):173442 .

Vaccaro LE, Bedford BL, Johnston CA. 2009. Litter accumulation promotes dominance of invasive species of cattails (Typha spp.) in Lake Ontario wetlands. Wetlands 29:1036-48.

van der Valk AG. 1981. Succession in wetlands: a Gleasonian approach. Ecology 62:688-96.

van der Valk AG, Verhoeven JTA. 1988. Potential role of seed banks and understory species in restoring quaking fens from floating forests. Vegetatio 76:3-13.

van Leeuwen CHA, van der Velde G, van Groenendael JM, Klaassen M. 2012. Gut travellers: internal dispersal of aquatic organisms by waterfowl. Journal of Biogeography 39:203140.

van Zuidam JP, van Leeuwen CHA, Bakker ES, Verhoeven JTA, Ijff S, Peeters ETHM, van Zuidam BG, Soons MB. 2018. Plant functional diversity and nutrient availability can improve restoration of floating fens via facilitation, complementarity and selection effects. Journal of Applied Ecology 56:1-11.
Vymazal J. 2014. Constructed wetlands for treatment of industrial wastewaters: a review. Ecological Engineering 73:724-51.

Vymazal J, Kröpfelová L. 2005. Growth of Phragmites australis and Phalaris arundinacea in constructed wetlands for wastewater treatment in the Czech Republic. Ecological Engineering 25:606-21

Wang $\mathrm{H}$, Chen Z-X, Zhang X-Y, Zhu S-X, Ge Y, Chang S-X, Zhang C-B, Huang C-C, Chang J. 2013. Plant species richness increased belowground plant biomass and substrate nitrogen removal in a constructed wetland. CLEAN-soil. Air, Water 41:657-64.

Webb JA, Wallis EM, Stewardson MJ. 2012. A systematic review of published evidence linking wetland plants to water regime components. Aquatic Botany 103:1-14.

Wichmann S. 2017. Commercial viability of paludiculture: a comparison of harvesting reeds for biogas production, direct combustion, and thatching. Ecological Engineering 103:497505.

Wickham H. 2009. ggplot2: elegant graphics for data analysis. New York: Springer. https://ggplot2.org.

Wickham H. 2011. The split-apply-combine strategy for data analysis. Journal of Statistical Software 40:1-29.

Wickham H. 2018. stringr: simple, consistent wrappers for common string operations. https://CRAN.R-project.org/packa ge $=$ stringr

Wickham H, Francois R, Henry L, Müller K. 2017. dplyr: a grammar of data manipulation. https://CRAN.R-project.org/ package $=$ dplyr

Wilcox, DA. 2011. Cattails as far as the eye can see. SWS Research Brief.

Zedler JB. 2000. Progress in wetland restoration ecology. Trends in Ecology \& Evolution 15:402-7.

Zedler JB, Kercher S. 2005. Wetland resources: status, trends, ecosystem services, and restorability. Annual Review of Environment and Resources 30:39-74.

Zhao X, Zhao Y, Wang J, Meng X, Zhang B, Zhang R, Wang T, Huang N, Wang S, Wang W. 2015. Design of a novel constructed treatment wetland system with consideration of ambient landscape. International Journal of Environmental Studies 72:146-53. 